\title{
Business Tourist Segment: Empirical Analysis in Spain about the Influence of Social Media and Smartphone in Reservations for Hotels
}

\author{
Joan-Francesc Fondevila-Gascón ${ }^{1,2,3,4, *}$, Gaspar Berbel ${ }^{5}$, Mònica Muñoz-González ${ }^{5}$, Pedro Mir-Bernal ${ }^{6}$, \\ Elena Puiggròs ${ }^{5}$, Javier Sierra-Sánchez ${ }^{7}$, Marta Tena-León ${ }^{8}$, Eva Santana-López ${ }^{9}$, Josep Rom-Rodríguez', \\ Enric Ordeix-Rigo 9
}

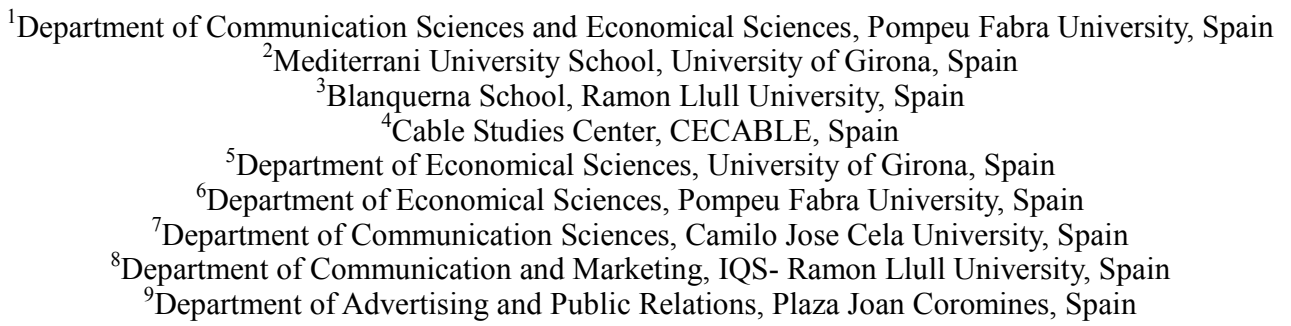

Copyright $\bigcirc 2016$ by authors, all rights reserved. Authors agree that this article remains permanently open access under the terms of the Creative Commons Attribution License 4.0 International License

\begin{abstract}
Smartphones and social media influence the decision to buy tourism goods, especially in the case of business. Specifically, we show that smartphone bookings made by business tourists coming to Barcelona are increasingly popular. Methodologically, we devised a quantitative questionnaire. Data collection was carried out for 4 months in 2015 with $n=1512$. We conducted a sieve with inclusion and exclusion criteria and which discarded all participants who did not travel for business. The final sample was 494 participants. We conclude that social media (Booking, TripAdvisor, Facebook, Twitter, Instagram and Foursquare) are used by youngers because people have known they belong to social network. Users consider the information provided by the companies in social media reliable. The most used means for contacting the accommodation are phone and email. The more useful apps are the hotels apps.
\end{abstract}

Keywords Smartphone, Social Media, Tourism, Marketing, Hotel, Business, Social Network, Internet

\section{Introduction}

The Information and Communications Technology (ICT) has a big impact on our society. The new generations assimilate naturally the new culture in this technological era. Nowadays, by using the new technological advances human beings have achieved things which were impossible to carry out previously. Hardware and software have been implemented in areas such as education, health, security, government or companies with the aim of managing information [1] [2].

This research intends to prove that social media influence on the decision to purchase tourist goods in a full-fledged Broadband Society [3] [4], leaded by cloud journalism and social journalism commerce. Specifically we have decided to prove that bookings made by using smartphones by business tourists in Barcelona are increasingly more usual.

More than half of Spaniards (76.2\%) between 16 and 74 years old use the Internet daily [5]. There are 26.2 million of Internet users (Internet users over the last three months), $1.45 \%$ more than in 2013. Frequent users (who connect at least once a week) account for $93.5 \%$ of total Internet users. The report also says that the device used to access the Internet when travelling is the smartphone (63.2\%) with Internet access using its own smartphone network; followed by laptops (including netbooks and tablets) with 31.6\% and other devices (PDAs, game consoles, etc.) with 6.3\%. Spain is the fourth European country in number of smartphones.

The weight of social media is increasing in tourism, and the use of smartphones can help the tourist enterprises. Booking and TripAdvisor are the main social media opinion platforms in this sector. Facebook is one the main social networks, and it increases impact thanks to brand fan pages, emerged in 2007 [6], the same year as the "Like" button, an idea that didn't come into being until 2009. Ever that moment, the main brands have increased their number of fans progressively above 15 million, with Coca-Cola, for instance, having reached more than 60 million. The loyalty, 
how related they feel, the Word on Mouth (WOM) and the love for the brand define four different kinds of fans on Facebook: "fanatic", "utilitarian", "self-expressive", and "authentic" [7]. It is argued that there is no direct connection between giving a "Like" and purchasing a brand.

Focusing a study on social media in the touristic sector, including responsible tourism [8] or public entities [9] has generated three lines of investigation in three different aspects of touristic communication: Advertisement, business management and production services. Digital media present themselves to tourism as some sort of information infrastructure or "infostructure", inside of which social networks are characterized by the role of active touristic information producers and distributors. Having analysed the influence of social networking in Business to Consumer (B2C), it has been detected that touristic 2.0 B2C websites must offer some kind of touristic product: an augmented product (accommodation + flights + touristic package deals) and that the user must be enabled to have his own account and give his opinion on the available. Available services become more specialized through mobile-device applications (for smartphones or tablets), and channels for the implementation of consumers' recommendations are advised, as they allow web content to be expanded and customer loyalty to flourish.

Smartphones help the tourists in their travel [10] [11] and have a significant impact on the activity of the trip. Today travellers are in constant search for information in order to reduce uncertainty and make use of their smartphones as assistants throughout all phases. Especially before and during the trip, they rely on mobile technology to simplify the trip looking for information on transportation, lodging, attractions and activities. Travellers also use smartphones in order to communicate with others, using like emails, phone calls, text messages and social networks [12]. On the other hand, smartphones also represent a tool for self-entertainment games, music, and photography, photo sharing, watching movies or reading news.

As regards the supply side, there are various categorizations in the scope of mTourism [13] [14] for the proposal to deploy the complexity and diversity of this topic. Kennedy and Gretzel-Eden (2012) have created two classifications [15], the first seven categories, depending on the application services related to travel. They are "Navigation", "Social", "Mobile Marketing", "Security/Emergency", "Transactional", "Information" and "Entertainment", which are divided into several sub-categories. The second is based on the level of customization and is classified into seven major areas, ranging from personal preferences -which indicate the highest level- to "Sensitive Location", "Security/Data Control", "Control by means of the Internet", "Addiction to content", "Cosmetic changes" and, ultimately, the applications that cannot be customized in any way and do not offer any type of interaction.

Besides studying conventional guidebooks for mobiles [16], there are investigation on basic location aware context
[17] [18] [19], augmented reality [19], the requests as well as mobile applications in the context of the business of various tourist service providers such as airlines [20], theme parks [21] [22], and hotels [23].

Companies try to create and strengthen the emotional links between brand and consumer in order to gain their loyalty, in the always on framework. Thus, quantitative data (number of followers) have to be complemented with qualitative data. Social networks are the ideal mean to improve this relation. The individuals who follow the brand are the ones who feel more affinity and are more willing to talk positively about it. Social networks have caused a change in the way that consumers and companies communicate each other. It has gone from a hierarchic and lineal scheme - with the company in the dominant position- to a bidirectional and egalitarian one with huge relevance put in the consumers. Brand management is shared with the public. Social networks have become a virtual environment for communication between consumers and companies where brand value is generated. This new kind of communication is more similar to friends' talk, rather than annoying advertising [24].

\section{Materials and Methods}

This research was based on a quantitative method that converts the object of study into numerical data, with emphasis on the objective measurement and, therefore, requiring the use of statistics [25]. For this study we decided to produce a quantitative questionnaire which is the usual method for data collection in the research and it using this type of method. The questionnaire is an instrument for obtaining data used to gather the information needed: facts, opinions and trends.

The questionnaire homogenises the information since all the subjects respond to the survey questions that are formulated in a standardized way, allowing information processing faster. We used the questionnaire that was designed to know the use of social media from a universe with Business as the main motivation for the trip.

First of all, there are a number of questions such the age, the sex, the origin and the level of education, on the one hand in order to see the profile of participants, and on the other hand to check how representative sample is. The various sets of questions want to know the reasons that motivate participants when participating in social media, the degree of confidence that they have, how the individual tourists organize their trip (before, during and after) and role of social media in these issues.

For the assessment of the majority of questions we used the Likert Scale, which measures attitudes toward a proposal depending on the respondent's degree of agreement or disagreement.

In quantitative research processes we usually select a representative sample of the population that is under study, so the results can be generalized to study the universe investigated [26].

Samples have some obvious advantages with respect to 
the study population, since with a restricted sample large populations can be surveyed and human, which otherwise would be very difficult.

\section{Results}

Data was collected over a 4 mounts period (May-August 2015) and 1,512 valid results were obtained. A streaming process was performed, using inclusive and exclusive criteria, and all those participants who were not on a business trip were discarded. The final sample included 494 participants (Tables $1 \& 2$ ).

Table 1. Data about the sample

\begin{tabular}{|c|c|c|c|c|}
\hline Name & Average & $\begin{array}{c}\text { Standard } \\
\text { Deviation }\end{array}$ & $\begin{array}{c}\text { Confidence } \\
\text { Index (95\%) }\end{array}$ & $\mathrm{N}$ \\
\hline Age & 38.92 & 10.30 & $(38.12$ a 40.13) & 494 \\
\hline
\end{tabular}

Source: own

Table 2. Name, sex, studies and origin of the sample

\begin{tabular}{|c|c|c|}
\hline Name & Categories & Percentage \\
\hline Sex & Women & $44.53 \%$ \\
\hline Studies & Secondary education & $27 \%$ \\
\hline & University studies & $72 \%$ \\
\hline Origin & Nationals & $57.4 \%$ \\
\hline & Internationals & $42.6 \%$ \\
\hline & UK & $22.33 \%$ \\
\hline & Germany & $14.16 \%$ \\
\hline & $\begin{array}{c}\text { Others (France, Italy, Belgium, } \\
\text { Argentina, Ecuador...) }\end{array}$ \\
\hline
\end{tabular}

Sources: own

In this study we saw that the most used device by business tourism is smartphone, next is the Laptop and the tablet in third position (Table 3).

Table 3. When I connect to Internet, I do with ... (indicate $\%$ of time)

\begin{tabular}{|c|c|c|c|c|}
\hline Name & $\%$ & $\begin{array}{c}\text { Standard } \\
\text { Deviation }\end{array}$ & $\begin{array}{c}\text { Confidence } \\
\text { Index (95\%) }\end{array}$ & $\mathrm{n}$ \\
\hline Desktop & 46.52 & 37.51 & $(43.73 ; 51.26)$ & 494 \\
\hline Laptop & 58.07 & 34.32 & $(53.97 ; 60.72)$ & 494 \\
\hline Smartphone & 62.84 & 31.27 & $(59.82 ; 65.99)$ & 494 \\
\hline Tablet & 41.80 & 39.15 & $(38.16 ; 45.87)$ & 494 \\
\hline Others devices & 1.60 & 10.91 & $(0.62 ; 2.78)$ & 494 \\
\hline
\end{tabular}

Sources: Own

Table 4 shows the least know social media are Instagram and Foursquare, which are below the average (2.5)

Table 4. Level of Knowledge of Social Media ( $0=$ nothing, $5=$ mastery)

\begin{tabular}{|c|c|c|c|c|}
\hline Name & $\begin{array}{c}\text { Average } \\
(0-5)\end{array}$ & $\begin{array}{c}\text { Standard } \\
\text { Deviation }\end{array}$ & $\begin{array}{c}\text { Confidence } \\
\text { Index (95\%) }\end{array}$ & $\mathrm{n}$ \\
\hline Facebook & 3.88 & 1.51 & $(3.74 ; 4.05)$ & 489 \\
\hline Twitter & 3.13 & 1.88 & $(2.97 ; 3.34)$ & 487 \\
\hline Google+ & 3.04 & 1.85 & $(2.94 ; 3.30)$ & 487 \\
\hline LinkedIn & 2.86 & 1.86 & $(2.63 ; 3.01)$ & 485 \\
\hline Instagram & 2.25 & 1.80 & $(2.09 ; 2.45)$ & 491 \\
\hline Foursquare & 0.93 & 1.44 & $(0.75 ; 1.03)$ & 490 \\
\hline TripAdvisor & 3.03 & 1.54 & $(2.85 ; 3.15)$ & 489 \\
\hline Booking & 3.67 & 1.37 & $(3.52 ; 3.80)$ & 491 \\
\hline
\end{tabular}

Sources: Own
Social media more used are Booking and TripAdvisor (Table 5), the only items over the average (2.5).

Table 5. Level of use of Social Media ( $0=$ no use, $1=$ few use; $5=$ much use)

\begin{tabular}{|c|c|c|c|c|}
\hline Name & $\begin{array}{c}\text { Average } \\
(0-5)\end{array}$ & $\begin{array}{c}\text { Standard } \\
\text { Deviation }\end{array}$ & $\begin{array}{c}\text { Confidence } \\
\text { Index (95\%) }\end{array}$ & $\mathrm{n}$ \\
\hline Facebook & 2.21 & 2.08 & $(2.05 ; 2.45)$ & 491 \\
\hline Twitter & 1.67 & 2.05 & $(1.49 ; 1.90)$ & 485 \\
\hline Google+ & 2.01 & 2.20 & $(1.84 ; 2.28)$ & 486 \\
\hline LinkedIn & 1.16 & 1.75 & $(1.02 ; 1.37)$ & 486 \\
\hline Instagram & 0.91 & 1.49 & $(0.75 ; 1.03)$ & 490 \\
\hline Foursquare & 0.48 & 1.11 & $(0.35 ; 0.55)$ & 487 \\
\hline TripAdvisor & 2.86 & 1.61 & $(2.64 ; 2.96)$ & 491 \\
\hline Booking & 3.59 & 1.44 & $(3.44 ; 3.73)$ & 492 \\
\hline
\end{tabular}

Sources: Own

Table 6 shows that the main motivation for using social media is the immediate communication with contacts, family and/or friends of the participants.

Table 6. Motivations that lead to use social media (1= strongly disagree, $5=$ totally agree)

\begin{tabular}{|c|c|c|c|c|}
\hline Item & $\begin{array}{c}\text { Average } \\
(1-5)\end{array}$ & $\begin{array}{c}\text { Standard } \\
\text { Deviation }\end{array}$ & $\begin{array}{c}\text { Confidence } \\
\text { Index (95\%) }\end{array}$ & $\mathrm{n}$ \\
\hline $\begin{array}{c}\text { Online social } \\
\text { networks are nice, } \\
\text { fun and I am proud to } \\
\text { share my opinions } \\
\text { and assessments }\end{array}$ & 3.62 & 1.21 & $(3.53 ; 3.77)$ & 492 \\
\hline $\begin{array}{c}\text { Online social } \\
\text { networks allow me to } \\
\text { stay in touch with my } \\
\text { friends/family and } \\
\text { contacts }\end{array}$ & 4.03 & 1.20 & $(3.99 ; 4.21)$ & 492 \\
\hline $\begin{array}{c}\text { Online social } \\
\text { networks make me } \\
\text { feel a sense of } \\
\text { belonging to a group }\end{array}$ & 3.05 & 1.53 & $(2.89 ; 3.19)$ & 492 \\
\hline $\begin{array}{c}\text { Most people around } \\
\text { me belong to } \text { a social } \\
\text { net-work online }\end{array}$ & 4.09 & 1.14 & $(4.04 ; 4.25)$ & 492 \\
\hline $\begin{array}{c}\text { I use them because } \\
\text { they are necessary } \\
\text { for my job }\end{array}$ & 3.18 & 1.62 & $(3.05 ; 3.37)$ & 492 \\
\hline $\begin{array}{c}\text { Online social } \\
\text { networks make my } \\
\text { life easier by } \\
\text { allowing me to solve } \\
\text { problems quickly }\end{array}$ & 3.43 & 1.41 & $(3.32 ; 3.60)$ & 492 \\
\hline $\begin{array}{c}\text { Online social } \\
\text { networks allow me to } \\
\text { follow the path of my } \\
\text { favorite companies }\end{array}$ & 3.41 & 1.42 & $(3.27 ; 3.55)$ & 492 \\
\hline $\begin{array}{c}\text { I use them because } \\
\text { others do so }\end{array}$ & 2.89 & 1.49 & $(2.73 ; 3.03)$ & 492 \\
\hline
\end{tabular}

Sources: Own

The degree of trust and privacy opinion on social media below $3(<3)$ is associated with the item "Information and comments offered by social networking companies inspire 
confidence." The reliability and confidence increase when information is offered to companies that choose to follow the participants (Table 7).

Table 7. Opinion on the trust and privacy of social media (1=strongly disagree, $5=$ totally agree)

\begin{tabular}{|c|c|c|c|c|}
\hline Item & $\begin{array}{l}\text { Average } \\
(1-5)\end{array}$ & $\begin{array}{l}\text { Standard } \\
\text { Deviation }\end{array}$ & $\begin{array}{l}\text { Confidence } \\
\text { Index } \\
\text { (95\%) }\end{array}$ & $\mathrm{n}$ \\
\hline $\begin{array}{l}\text { I believe that my } \\
\text { personal data are } \\
\text { properly treated in } \\
\text { social networks online }\end{array}$ & 2.94 & 1.23 & $\begin{array}{l}(2.85 \\
3.09)\end{array}$ & 492 \\
\hline $\begin{array}{l}\text { Privacy measures of } \\
\text { online social networks } \\
\text { inspire sufficient } \\
\text { confidence to continue } \\
\text { using them }\end{array}$ & 3.13 & 1.13 & $\begin{array}{l}(3.05 \\
3.27)\end{array}$ & 492 \\
\hline $\begin{array}{l}\text { The information I } \\
\text { provide is trented safely }\end{array}$ & 3.08 & 1.18 & $\begin{array}{c}(3.04 \\
3.26)\end{array}$ & 492 \\
\hline $\begin{array}{l}\text { The information } \\
\text { provided by the } \\
\text { companies I follow are } \\
\text { reliable }\end{array}$ & 3.37 & 1.12 & $\begin{array}{l}(3.32 \\
3.54)\end{array}$ & 492 \\
\hline $\begin{array}{l}\text { I stopped publishing my } \\
\text { opinions because I'm } \\
\text { not really want to be } \\
\text { seen by others }\end{array}$ & 3.24 & 1.14 & $\begin{array}{l}(3.19 ; \\
3.42)\end{array}$ & 492 \\
\hline $\begin{array}{l}\text { The information and } \\
\text { comments provided by } \\
\text { businesses on social } \\
\text { networks inspire } \\
\text { confidence }\end{array}$ & 2.63 & 1.09 & $\begin{array}{l}(2.50 \\
2.77)\end{array}$ & 492 \\
\hline $\begin{array}{l}\text { Information on online } \\
\text { social networks has } \\
\text { helped me in my } \\
\text { purchase decisions }\end{array}$ & 3.31 & 1.17 & $\begin{array}{l}(3.24 \\
3.47)\end{array}$ & 492 \\
\hline $\begin{array}{l}\text { The information found } \\
\text { on online social } \\
\text { networks seems reliable }\end{array}$ & 3.18 & 1.09 & $\begin{array}{l}(3.11 \\
3.32)\end{array}$ & 492 \\
\hline
\end{tabular}

Sources: Own

Table 8. When arranging a trip ( $1=$ strongly disagree, $5=$ totally agree $)$

\begin{tabular}{|c|c|c|c|c|}
\hline Item & $\begin{array}{c}\text { Average } \\
(1-5)\end{array}$ & $\begin{array}{c}\text { Standard } \\
\text { Deviation }\end{array}$ & $\begin{array}{c}\text { Confidence } \\
\text { Index (95\%) }\end{array}$ & $\mathrm{n}$ \\
\hline $\begin{array}{c}\text { I look for } \\
\text { information on the } \\
\text { Social Networking }\end{array}$ & 3.53 & 1.48 & $(3.47 ; 3.76)$ & 492 \\
\hline $\begin{array}{c}\text { I look for } \\
\text { information on the } \\
\text { pages of tourism } \\
\text { providers (airline, } \\
\text { hotel, etc.) }\end{array}$ & 3.97 & 1.23 & $(3.89 ; 4.13)$ & 492 \\
\hline $\begin{array}{c}\text { I look for } \\
\text { information from } \\
\text { traditional travel } \\
\text { agencies }\end{array}$ & 3.15 & 1.52 & $(3.05 ; 3.35)$ & 492 \\
\hline $\begin{array}{c}\text { I book my trip on the } \\
\text { Media/Social } \\
\text { Network }\end{array}$ & 3.04 & 1.56 & $(2.96 ; 3.27)$ & 492 \\
\hline $\begin{array}{c}\text { I book my trip in the } \\
\text { pages of tourism } \\
\text { providers (airline, } \\
\text { hotel, etc.) }\end{array}$ & 3.91 & 1.22 & $(3.81 ; 4.05)$ & 492 \\
\hline $\begin{array}{c}\text { I book my trip at } \\
\text { traditional travel } \\
\text { agencies }\end{array}$ & 3.09 & 1.53 & $(2.97 ; 3.27)$ & 492 \\
\hline
\end{tabular}

Sources: Own
When organizing a trip, the participants seem to prefer to seek information and engage primarily in the pages of suppliers, fully exceeding the average (3) (Table 8).

Table 9 shows that participants interact with media/social network especially while travelling.

Table 9. Value if you perform the following actions regarding the use of Media/Social networks before, during and after the trip (1=strongly disagree, $5=$ totally agree)

\begin{tabular}{|c|c|c|c|c|}
\hline Item & $\begin{array}{c}\text { Average } \\
(1-5)\end{array}$ & $\begin{array}{l}\text { Standard } \\
\text { Deviation }\end{array}$ & $\begin{array}{l}\text { Confidence } \\
\text { Index (95\%) }\end{array}$ & $\mathrm{n}$ \\
\hline $\begin{array}{c}\text { Before departing, I } \\
\text { let my acquaintances } \\
\text { know Media/Social } \\
\text { Networks }\end{array}$ & 2.58 & 1.41 & $(2.47 ; 2.75)$ & 492 \\
\hline $\begin{array}{l}\text { Before departing I } \\
\text { look at the opinions } \\
\text { of other travel } \\
\text { agency users }\end{array}$ & 3.13 & 1.36 & $(3.07 ; 3.34)$ & 492 \\
\hline $\begin{array}{l}\text { Before departing I } \\
\text { look at other hotel } \\
\text { guests' opinions }\end{array}$ & 3.62 & 1.31 & $(3.573 .83)$ & 492 \\
\hline $\begin{array}{l}\text { During the trip, I } \\
\text { look for reviews of } \\
\text { Restaurants }\end{array}$ & 3.69 & 1.25 & $(3.64 ; 3.88)$ & 492 \\
\hline $\begin{array}{c}\text { During the trip, I } \\
\text { look for reviews of } \\
\text { places to visit }\end{array}$ & 3.80 & 1.20 & $(3.76 ; 3.99)$ & 492 \\
\hline $\begin{array}{c}\text { After the trip I } \\
\text { communicate my } \\
\text { impressions }\end{array}$ & 3 & 1.47 & $(2.89 ; 3.17)$ & 492 \\
\hline $\begin{array}{l}\text { After the trip I value } \\
\text { travel agencies, } \\
\text { Hotels, Restaurants }\end{array}$ & 3.03 & 1.36 & $(2.94 ; 3.21)$ & 492 \\
\hline
\end{tabular}

Sources: Own

Table 10 shows that most used media/social networks are Facebook and Booking exceeding the average value (3)

Table 10. Indicate the degree in which you have used Media/Social Network on this trip $(1=$ rarely or never, $5=$ ever $)$

\begin{tabular}{|c|c|c|c|c|}
\hline Item & $\begin{array}{c}\text { Average } \\
(1-5)\end{array}$ & $\begin{array}{c}\text { Standard } \\
\text { Deviation }\end{array}$ & $\begin{array}{c}\text { Confidence } \\
\text { Index (95\%) }\end{array}$ & $\mathrm{n}$ \\
\hline Facebook & 3.38 & 1.55 & $(3.30 ; 3.60)$ & 491 \\
\hline Twitter & 2.83 & 1.69 & $(2.75 ; 3.08)$ & 490 \\
\hline Google+ & 2.54 & 1.68 & $(2.44 ; 2.78)$ & 490 \\
\hline LinkedIn & 2.48 & 1.59 & $(2.33 ; 2.64)$ & 489 \\
\hline Instagram & 2.12 & 1.41 & $(2 ; 2.29)$ & 490 \\
\hline Foursquare & 1.39 & 0.86 & $(1.30 ; 1.46)$ & 486 \\
\hline TripAdvisor & 2.65 & 1.40 & $(2.50 ; 2.78)$ & 491 \\
\hline Booking & 3.11 & 1.49 & $(2.97 ; 3.26)$ & 491 \\
\hline
\end{tabular}

Sources: Own

The data in Table 11 show that the most used means for contacting the accommodation are phone and email, which far exceed the average (3) and the website, which also has a higher value than the average. 
Table 11. When you want to contact the accommodation, which means do you use more often? ( $1=$ rarely or never, $5=$ ever)

\begin{tabular}{|c|c|c|c|c|}
\hline Item & $\begin{array}{c}\text { Average } \\
(1-5)\end{array}$ & $\begin{array}{c}\text { Standard } \\
\text { Deviation }\end{array}$ & $\begin{array}{c}\text { Confidence } \\
\text { Index (95\%) }\end{array}$ & $\mathrm{n}$ \\
\hline Phone & 3.82 & 1.38 & $(3.72 ; 3.99)$ & 491 \\
\hline Email address & 3.81 & 1.31 & $(3.76 ; 4.01)$ & 489 \\
\hline Social Networks & 2.81 & 1.58 & $(2.70 ; 3.02)$ & 490 \\
\hline Website & 3.46 & 1.37 & $(3.36 ; 3.62)$ & 487 \\
\hline $\begin{array}{c}\text { Opinion portals } \\
\text { (TripAdvisor, } \\
\text { Booking, etc.) }\end{array}$ & 2.99 & 1.62 & $(3.06 ; 3.36)$ & 485 \\
\hline $\begin{array}{c}\text { Others (indicate } \\
\text { which) }\end{array}$ & 1.14 & 0.67 & $(1.06 ; 1.19)$ & 459 \\
\hline
\end{tabular}

Sources: Own

In the case of the Apps (Table 12) we see that those perceived as more useful are those of Hotels, exceeding the average (2.5).

Table 12. Evaluate the degree of usefulness of mobile apps ( $0=$ don't use, $1=$ nothing useful and $5=$ very helpful)

\begin{tabular}{|c|c|c|c|c|}
\hline Item & $\begin{array}{c}\text { Average } \\
(0-5)\end{array}$ & $\begin{array}{c}\text { Standard } \\
\text { Deviation }\end{array}$ & $\begin{array}{c}\text { Confidence } \\
\text { Index (95\%) }\end{array}$ & $\mathrm{n}$ \\
\hline App Hotels & 2,64 & 1,80 & $(2,41 ; 2,77)$ & 492 \\
\hline $\begin{array}{c}\text { App Travel } \\
\text { Agencies }\end{array}$ & 2,12 & 1,80 & $(1,96 ; 2,32)$ & 492 \\
\hline
\end{tabular}

Source: Own

\section{Discussion}

This research confirms the links between tourism, social media and smartphones use. Considering [27], three quarters of travellers attend comments from other online consumers as a reference to plan their trips. Therefore, and given our results, social media are a reference when travelling or consuming "tourism" by other Internet users.

The consumer's opinion websites allow travellers to review any aspects of a vacation, including lodging, restaurants, destinations and other tourism-related products, such as tour operators. It is a key factor to evaluate the quality of digital contents [28]. In the case of journalism, it is a way to success [29] [30]. As soon as you publish comments on the networks, they are available to other potential travellers to read and make use to make decisions later [31].

eWOM communication articulated by opinion platforms based on the opinions of consumers have greater impact than other opinions published in other Media, because, unlike other groups, opinion platforms are relatively easy to use and require less knowledge surfer from consumers who want to get information [32].

The results of our investigation show that most travellers believe the information provided by the social media users is less biased, credible and reliable information when compared with traditional organizations.

\section{Conclusions}

In our research we find that most travellers believe that the information provided by the users in social media is less biased. It is a more credible and reliable information compared to traditional organizations. Thus we observe that the participants interact with the social networks especially while travelling. Always on factor is necessary. But when an organized trip, participants prefer to recruit primarily seek information and pages of providers.

In our research we found that, in general, in younger participants, the use of social media increases among young people, especially in Foursquare, Instagram and Twitter; less in Facebook. With other social media (Google+, LinkedIn, TripAdvisor and Booking), the association is not significant.

The research also reveals that the more used social media are TripAdvisor and Booking. It is a key factor considering that users sometimes have to look for accommodation for business trips. The platforms confirm the weight of their opinions. One of the first steps of tourists before choosing accommodation is consult the opinions in this type of platform. This is one of the reasons why the hotel establishments are enhancing their digital communication, for the purpose of answering this growing need for online reputation built through social media.

In our study, we demonstrated the age and level of education determines the contact establishments and even the search for information before, during and after the trip. Thus, the variables social networks and web portal have a significant association; thus, it confirms that younger age increases the use of social media by making contact with the accommodation.

Another relevant data is the age of participants. Social media like Facebook, Twitter, Instagram and Foursquare are the way used by young people. Gender does not influence their use, in general. It also seems relevant the fact that gender is significant in some of the actions of users on the use of social media. We noted that some results had a tendency for business women more often than men seek the views of other social media users. Even some items this habit can reach up to half a point increase over the masculine.

In general, the results allow us to interpret our research participants consider social media a tool that provides access to the tourism sector, which allows them to contact the provider at the time of booking of tourist service whatever. This enables intensive relations between the consumer and the service provider, potentially reaching a greater volume of business and the ability to lower the costs of intermediaries. But we also see the results that the main motivation for use of social media is immediate communication with contacts, family or friends of participants.

Regression models show age has a significant effect on the response of all items about use of social media before, during and after the trip, with the exception of the item "During the trip looking for reviews of restaurants", where age does not influence, but does gender. This shows a general trend, which tells us that business women look more 
often the views of other social media users. In some items, this habit can be increased to reach half a point above men. In general, we see the regression models that both age and gender, in this case young people and women, generate more influence in the intention to communicate and express themselves using social media.

\section{REFERENCES}

[1] J. F. Fondevila, S. Estella, J. L. Del Olmo. Estrategias de gestión de la información para cubrir necesidades laborales especializadas, ICONO14, Vol. 11, No. 1, 217-231, 2013

[2] J. F. Fondevila. Investigación sobre Tecnologías de la Información y la Comunicación en turismo, III Jornada AECIT (Asociación Española de Expertos Científicos en Turismo) sobre proyectos de investigación en turismo. Escola Universitària Mediterrani (Universitat de Girona), Barcelona, 2015.

[3] J. F. Fondevila. El cloud journalism: un nuevo concepto de producción para el periodismo del siglo XXI, Observatorio (OBS*) Journal, Vol. 4, No. 1, 19-35, 2010.

[4] J. F. Fondevila. Periodismo ciudadano y cloud journalism: un flujo necesario en la Sociedad de la Banda Ancha, Comunicación y Hombre, No. 9, 25-41, 2013.

[5] INE. La Sociedad de la Información en España, Madrid, INE, 2014.

[6] L. De Vries, S. Gensler, P.S.H. Leeflang. Popularity of Brand Posts on Brand Fan Pages: An Investigation of the Effects of Social Media Marketing. Journal of Interactive Marketing, Vol. 26, No. 2, 83-91, 2012.

[7] E. Wallace, I. Buil, L. De Chernatony, M. Hogan. Who "Likes" You... and Why? A typology of Facebook Fans, Journal of Advertising Research, Vol. 54, No. 1, 92-109, 2014.

[8] J. F. Fondevila, A. Soliguer. Commercialization Formulas of the Responsible Tourism in Spain: Reality and Trends, I Congreso Internacional OCITUR 2012-Primer Congreso de Ocio y Turismo. Ocio y Turismo del Siglo XXI-Perspectivas de Futuro. Mataró, 2012.

[9] J. F. Fondevila, P. Mir, M. Muñoz. Comunicación digital: uso de redes sociales en "Turisme de Barcelona". I Congreso Internacional Comunicación y Pensamiento. Grupo de Investigación en Estructura, Historia y Contenidos de la Comunicación (GREHCCO) y el Laboratorio de Estudios en Comunicación (LADECOM) de la Facultad de Comunicación de la Universidad de Sevilla, Sevilla, 2016.

[10] M. Kenteris, D. Gavalas, D. Economou. An innovative mobile electronic tourist guide application, Personal and Ubiquitous Computing, Vol. 13, No. 2, 103-118, 2009.

[11] Y. Wang, J. Kracht. Examining the tourism distribution channel: evolution and transformation, International Journal of Contemporary Hospitality Management, Vol. 22, No. 5, 736-757, 2010.

[12] J. F. Fondevila, J. L. Del Olmo, V. Bravo. Presencia y reputación digital en social media: comparativa en el sector de la moda, Fonseca, Journal of Communication, No. 5, 92-116, 2012.

[13] H. Kennedy-Eden, U. Gretzel. A taxonomy of mobile applications in tourism, E-review of Tourism Research, Vol. 10, No. 2, 47-50, 2012.

[14] D. Wang, Z. Xiang. The new land scape of travel: a comprehensive analysis of smartphone apps, in M. Fuchs, F. Ricci, L. Cantoni (eds.), Information and communication technologies in tourism (pp. 308-315), Vienna, Springer, 2012.

[15] H. Kennedy-Eden, U. Gretzel. A taxonomy of mobile applications in tourism, E-review of Tourism Research, Vol. 10, No. 2, 47-50, 2012.

[16] J. Rasinger, M. Fuchs, W. Höpken, T. Beer. Information Search with Mobile Tourist Guides: A Survey of Usage Intention, Information Technology \& Tourism - Applications, Methodologies, Techniques, Vol. 9, No. 3, 2007.

[17] W. Höpken, M. Fuchs, M. Zanker, T. Beer. Context-based adaptation of mobile applications in tourism, Information Technology and Tourism, Vol. 12, No. 2, 175-195, 2010.

[18] A. B. Barragán-Martínez, E. Costa-Montenegro, E. Adding personalization and social features to a context-aware application for mobile tourism, in A. Waising Loo (ed.), Distributed computing innovations for business, engineering, and science (pp. 253-265), Hershey, Information Science Reference, 2013.

[19] C. Lamsfus, D. Martín, A. Alzua-Sorzabal, A. Cadenas, C. Ruiz, R. García-Castro, M. Poveda. Servicios turísticos en función del contexto basados en semántica, XIX Jornadas Telecom I+D (Telecom I+D 2009), Madrid, Spain, 2009.

[20] Z. Yovcheva, D. Buhalis, C. Gatzidis, C. Smartphone Augmented Reality Applications for Tourism, e-Review of Tourism Research (eRTR), Vol. 10, No. 2, 63-66, 2012.

[21] Y. Liu, R. Law. Information and Communication Technologies in Tourism 2013, Proceedings of the International Conference, Innsbruck, Austria, 2013.

[22] A. Brown, J. Kappes, J. Marks, J. Mitigating theme park crowding with incentives and information on mobile devices, Journal of Travel Research, Vol. 20, No. 10, 1-11, 2013.

[23] D. Kim, H. Alder. Student's Use of Hotel Mobile Application: Their Effect on Brand Loyalty, New Jersey, Pearson Prentice Hall, 2011.

[24] B. Jahn, W. Kunz W. How to transform consumers into fans of your brand, Journal of Service Management, Vol. 23, No. 3, 344-361, 2012.

[25] J. F. Fondevila, J. L. Del Olmo. El Trabajo de Fin de Grado en Ciencias Sociales y Jurídicas. Guía metodológica, Madrid, Ediciones Internacionales Universitarias, 2013.

[26] J. F. Fondevila, J. L. Del Olmo. El Trabajo de Fin de Grado en Ciencias Sociales y Jurídicas. Guía metodológica, Madrid, Ediciones Internacionales Universitarias, 2013.

[27] U. Gretzel, K. H. Yoo (2008). Use and impact of online travel reviews, in P. O'Connor, W. Höpken, U. Gretzel (eds.), Information and communication technologies in tourism (pp. 35-46), New York, Springer, 2008.

[28] J. F. Fondevila. El uso de hipertexto, multimedia e interactividad en periodismo digital: propuesta metodológica 
de ranking de calidad, ZER, Revista de Estudios de Comunicación (Journal of Communication Studies), Vol. 19, No. 36, 55-76, 2014.

[29] J. F. Fondevila. El uso de recursos del periodismo digital en la prensa del Reino Unido, Francia, Estados Unidos y España, Estudios sobre el Mensaje Periodístico (EMP), Vol. 18, No. 1, 73-87, 2012.

[30] J. F. Fondevila, H. Segura. El peso de la hipertextualidad en el periodismo digital: estudio comparativo, Cuadernos de
Información, 30, 31-40, 2012.

[31] M. Sigala, E. Christou, U. Gretzel. Social Media in Travel, Tourism and Hospitality: Theory, Practice and Cases. Surrey, UK: Ashgate, 2012.

[32] T. Hennig-Thurau, K. P. Gwinner, G. Walsh, D. Gremler. Electronic Word-of-Mouth via Consumer-Opinion Platforms: What Motivates Consumers to Articulate Themselves on the Internet?, Journal of Interactive Marketing, Vol. 18, No. 1, 38-52, 2004. 